\title{
AN OVERVIEW ON THE VULNERABILITIES OF NONGOVERNMENTAL ORGANIZATIONS
}

\author{
Mihaela PĂCEŞILĂ \\ E-Mail: pacesilamihaela@gmail.com \\ Associate Professor, PhD. Department of Administration and Public \\ Management, \\ Bucharest University of Economic Studies, Romania
}

\begin{abstract}
The purpose of this paper is to provide an overview of the existing body of literature on the vulnerabilities of nongovernmental sector. A review of previous literature based on 12 databases search (Clarivate Analytics/ISI Web of Science, EBSCO, Emerald, JSTOR, ProQuest, Sage, ScienceDirect, Scopus, Elsevier, Springer, CEEOL, DOAJ, RePEc) was carried out in order to find answers to the research questions. The final database included 71 publications, but after removing duplicates, a total of 30 publications from 1991 to mid-2020 were analyzed. Their investigation showed a slight increase in the relevance of this topic within academia. The analysis focused on the following aspects: journals covering the field of study, appearance of the first publications, main aspects approached by the papers under analysis. The contribution of this article consists in elaborating a multilevel framework of nongovernmental sector's vulnerabilities, focusing on the systematization of the results obtained in the field.
\end{abstract}

Key words: financial vulnerability; resource dependence; criteria; revenue diversification.

\section{INTRODUCTION}

Nongovernmental organizations can be referred to as voluntary organizations, nonprofit organizations, charities, or without lucrative purpose organizations. The term "nonprofit organizations" is mainly used in the United States of America (Dang, 2009) although other authors (Ahmed \& Potter, 2006) highlight that NGOs (nongovernmental organizations) and NPOs (nonprofit organizations) are considered approximately synonymously in that country. As regards Europe, there are many terms defining these organizations depending on the culture in which they have developed (Paceșilă, 2016). 
The nonprofit concept avoiding, at any cost, the notion of profit, as a positive difference between the revenue and expenditure of the organization at the end of the fiscal year, should not be seen in absolute terms. It is atypical for nongovernmental organizations to have empty accounts at the end of the fiscal year (Adirondack, 1999). The nonprofit term shows that the profit recorded at the end of the fiscal year will not be distributed to one or more individuals within the organization, but it will be used to carry out the organization's activities (Hudson, 1995; Nicolae, 2010). The concept of profit, as a positive difference between revenue and expense, is not appropriate to describe the cash surplus available to the organization at the end of the fiscal year.

Nongovernmental organizations are agents of human change (Roshayani, Mohd Nisham, Nur Erzan, Ruhaini and Ramesh, 2018). Their product will always be related to the transformation, improvement of physical or mental comfort, care of human or mental health, protection of the unemployed persons, orphaned children or other disadvantaged people, protection of human rights in general or minorities in particular. The objective of nongovernmental organizations is always linked to the social good, even if the beneficiaries are not society as a whole, but only a part of it (Jura, 2003; Păceșilă \& Colesca, 2019; Kacarski \& Kovachevski, 2019).

\section{FACTORS CONTRIBUTING TO NONGOVERNMENTAL'S SECTOR VULNERABILITY}

In his criticism of nongovernmental organizations, the American sociologist David Harvey (2005) considers them one of the Western system's vulnerabilities that could destroy it from the inside. Their vulnerability comes from the following considerations:

- They may fall prey to external interests in their continuous search for funding.

- They may be ineffective because they pay a lot of attention to the interests of their members.

- They may be considered elitist because of their arrogance showed in relation to their beneficiaries.

In general, nongovernmental organizations do not perceive beneficiaries as active participants but as those who receive something (Păceșilă, 2016):

- Who and how the needs identified and who identifies them? There are few situations where the target group is consulted and involved in defining its needs.

- The opinion that nongovernmental organizations' members are experts: often the members of these organizations consider they are the only ones having the ideas that best meet the beneficiaries' needs.

- The beneficiaries understand their rights and role: organizations claim that beneficiaries are passive and do not require better services; on the other hand, beneficiaries may require too much.

- Cultural issues: many organizations say that interacting with communities, especially the rural ones, is a challenge because of past 
inheritances (people are suspicious and do not trust the strangers).

Another vulnerability highlighted by the specialists is that the nongovernmental sector is increasingly turning into an industry, despite the interests it theoretically serves. Thus, the so-called organizations born out of the rush for projects and funding are emerging. This raises many questions regarding the achievement of the real goal set at the founding of these organizations (Cihodariu, 2013; Naroș \& Simionescu, 2019; Esayas \& Mulugeta, 2020).

The Middle East governments are reluctant acknowledge nongovernmental organizations because they show instability and inconsistency in their relationship with the state (Pinfari, 2016). Moreover, they are allied with that part of the conflict seeking to maintain peace and stability, which greatly relieves NGO work. In fact, in many situations these organizations have been involved in political activity and have ended up becoming instruments of belligerents, supporting the rebel armies (for example the case of Ethiopia in the 1980s as well as Somalia and Sudan in the 19'-90).

However, nongovernmental organizations are an example of success in Europe and worldwide, being created for the consolidation of democracy. Although a regime is theoretically democratic, according to the neoliberal paradigm, the state should not be regarded as the sole author and guarantor of democracy. That is why certain democratic activities should be outsourced to the third sector's organizations positioned somewhere between the public and private sector and created to provide a democracy by proxy.

\section{METHODOLOGY}

This article addresses the concept of nongovernmental sector's vulnerability by examining the elements underlying the vulnerability of NGOs. In order to get an overview of the research field, the main issues emerging from the papers analyzed regarding the vulnerability of the third sector organizations are identified.

In this regard a review of previous literature based on a search of 12 databases. Systematic reviews are a type of literature review summarizing the results of a particular field of study in order to identify the main trends and developments (Aromataris and Pearson, 2014). This research method requires setting a detailed and complete plan as well as a search strategy in order to identify all the relevant studies on a particular research topic (Uman, 2011).

Data were collected from two categories of academic databases (table 1 and table 2): databases accessed within the ANELIS PLUS project (Clarivate Analytics/ISI Web of science, EBSCO, Emerald, JSTOR, ProQuest, Sage, ScienceDirect, Scopus, Elsevier, Springer); and open access databases (CEEOL, DOAJ, RePEc). Publications were gathered using the keywords "vulnerability of nongovernmental organizations/NGOs" and "vulnerability of nonprofit organizations/NPO" in titles. The search was done in several databases in order to get as much information as possible. Given the difficulties regarding the definition of these organizations and the disputes on the conceptualization of the sector (Ahmed \& Potter, 2006; Salamon \& 
Sokolowski, 2014), the research was carried out starting from two terms: NGOs and NPOs. The first shows that they are not governmental organizations, while the second that they are not profit-oriented entities.

Table 1 The study of nongovernmental sector's vulnerability in the literature databases accessed within the Anelis Plus project

\begin{tabular}{|c|c|c|c|}
\hline Database & Period & $\begin{array}{c}\text { Relevant } \\
\text { publications }\end{array}$ & Key word \\
\hline \multirow{2}{*}{$\begin{array}{l}\text { Clarivate } \\
\text { Analytics }\end{array}$} & \multirow{2}{*}{$\begin{array}{l}1975- \\
2020\end{array}$} & 2 articles & $\begin{array}{c}\text { Vulnerability of nongovernmental } \\
\text { organizations/NGOs }\end{array}$ \\
\hline & & $\begin{array}{c}7 \text { articles, } 2 \\
\text { proceedings papers }\end{array}$ & $\begin{array}{c}\text { Vulnerability of nonprofit } \\
\text { organizations/NPOs }\end{array}$ \\
\hline \multirow{2}{*}{ EBSCO } & \multirow{2}{*}{$\begin{array}{l}1900- \\
2020\end{array}$} & 1 article & $\begin{array}{c}\text { Vulnerability of nongovernmental } \\
\text { organizations/NGOs }\end{array}$ \\
\hline & & 8 articles & $\begin{array}{c}\text { Vulnerability of nonprofit } \\
\text { organizations/NPOs }\end{array}$ \\
\hline \multirow{2}{*}{ Emerald } & \multirow{2}{*}{$\begin{array}{l}1898- \\
2020\end{array}$} & - & $\begin{array}{c}\text { Vulnerability of nongovernmental } \\
\text { organizations/NGOs }\end{array}$ \\
\hline & & 1 article & $\begin{array}{c}\text { Vulnerability of nonprofit } \\
\text { organizations/NPOs }\end{array}$ \\
\hline \multirow{2}{*}{ JSTOR } & \multirow{2}{*}{$\begin{array}{l}1910- \\
2020\end{array}$} & 1 article & $\begin{array}{c}\text { Vulnerability of nongovernmental } \\
\text { organizations/NGOs }\end{array}$ \\
\hline & & 1 article & $\begin{array}{c}\text { Vulnerability of nonprofit } \\
\text { organizations/NPOs }\end{array}$ \\
\hline \multirow[b]{2}{*}{ ProQuest } & \multirow[b]{2}{*}{$\begin{array}{l}1930- \\
2020\end{array}$} & $\begin{array}{l}2 \text { articles, } 1 \\
\text { dissertation }\end{array}$ & $\begin{array}{c}\text { Vulnerability of nongovernmental } \\
\text { organizations/NGOs }\end{array}$ \\
\hline & & $\begin{array}{c}13 \text { articles, } 1 \\
\text { working paper, } 5 \\
\text { dissertations }\end{array}$ & $\begin{array}{l}\text { Vulnerability of nonprofit } \\
\text { organizations/NPOs }\end{array}$ \\
\hline \multirow{2}{*}{ Sage } & \multirow{2}{*}{$\begin{array}{l}1847- \\
2020\end{array}$} & - & $\begin{array}{c}\text { Vulnerability of nongovernmental } \\
\text { organizations/NGOs }\end{array}$ \\
\hline & & 1 article & $\begin{array}{c}\text { Vulnerability of nonprofit } \\
\text { organizations/NPOs }\end{array}$ \\
\hline \multirow{2}{*}{$\begin{array}{l}\text { Science } \\
\text { Direct }\end{array}$} & \multirow{2}{*}{$\begin{array}{l}1925- \\
2020\end{array}$} & - & $\begin{array}{c}\text { Vulnerability of nongovernmental } \\
\text { organizations/NGOs }\end{array}$ \\
\hline & & - & $\begin{array}{l}\text { Vulnerability of nonprofit } \\
\text { organizations/NPOs }\end{array}$ \\
\hline \multirow{2}{*}{$\begin{array}{l}\text { Scopus, } \\
\text { Elsevier }\end{array}$} & $\begin{array}{l}1971- \\
2020\end{array}$ & 2 articles & $\begin{array}{c}\text { Vulnerability of nongovernmental } \\
\text { organizations/NGOs }\end{array}$ \\
\hline & $\begin{array}{l}1979- \\
2020\end{array}$ & $\begin{array}{l}10 \text { articles, } 3 \\
\text { proceedings papers }\end{array}$ & $\begin{array}{c}\text { Vulnerability of nonprofit } \\
\text { organizations/NPOs }\end{array}$ \\
\hline \multirow{2}{*}{ Springer } & $\begin{array}{l}1967- \\
2020\end{array}$ & $\begin{array}{l}2 \text { articles, } 1 \text { book } \\
\text { chapter }\end{array}$ & $\begin{array}{c}\text { Vulnerability of nongovernmental } \\
\text { organizations/NGOs }\end{array}$ \\
\hline & $\begin{array}{l}1951- \\
2020\end{array}$ & 3 articles & $\begin{array}{c}\text { Vulnerability of nonprofit } \\
\text { organizations/NPOs }\end{array}$ \\
\hline
\end{tabular}

Source: Author, 2019

Most of these academic databases used in the search are included in the minimal standards for filling the position of associate professor and professor, the field of administrative science, higher education, mentioned by the Romanian Ministry of Education in accordance with The Law of National 
Education no. 1/2011with subsequent modifications and amendments.

The ANELIS PLUS project is being carried out by the Ministry of Education in order to respond to the increasing needs of information and documentation of users in Romania. It provides the academic and research community (teachers, researchers, students, master students, PhD students, postdoctoral students) with access to electronic information and documentation resources (ANELIS, n.d.).

Elsevier, Sage and Emerald are large publishers, recognized at international level, providing access to collections of scientific resources edited under their coordination. On the other hand, Proquest and Ebsco are "library" databases, providing access to resources edited by various publishers (including those mentioned above), universities (including doctoral and master theses), academic societies and professional associations around the world.

The open access databases provide free access to various publications including article indexes and abstracts, and occasional full text.

Table 2 The study of nongovernmental sector's vulnerability in the literature

\begin{tabular}{|c|c|c|c|}
\hline Database & Period & $\begin{array}{c}\text { Relevant } \\
\text { publications }\end{array}$ & Key word \\
\hline \multirow{2}{*}{ CEEOL } & \multirow{2}{*}{$\begin{array}{l}1950- \\
2020\end{array}$} & - & $\begin{array}{c}\text { Vulnerability of nongovernmental } \\
\text { organizations/NGOs }\end{array}$ \\
\hline & & - & $\begin{array}{l}\text { Vulnerability of nonprofit } \\
\text { organizations/NPOs }\end{array}$ \\
\hline \multirow{2}{*}{ DOAJ } & \multirow{2}{*}{-} & - & $\begin{array}{c}\text { Vulnerability of nongovernmental } \\
\text { organizations/NGOs }\end{array}$ \\
\hline & & 1 article & $\begin{array}{c}\text { Vulnerability of nonprofit } \\
\text { organizations/NPOs }\end{array}$ \\
\hline \multirow{2}{*}{ RePEc } & \multirow{2}{*}{-} & 1 working paper & $\begin{array}{c}\text { Vulnerability of nongovernmental } \\
\text { organizations/NGOs }\end{array}$ \\
\hline & & $\begin{array}{c}2 \text { articles, } 1 \\
\text { working paper }\end{array}$ & $\begin{array}{l}\text { Vulnerability of nonprofit } \\
\text { organizations/NPOs }\end{array}$ \\
\hline
\end{tabular}

Source: Author, 2020

The keywords used generated 71 relevant publications as follows:

- 12 publications from databases accessed within the ANELIS PLUS project (10 articles, 1 book chapter, 1 dissertation) and 1 publication from open access databases (1 working paper). All publications were generated by using the keyword vulnerability of nongovernmental organizations.

- 54 publications from databases accessed within the ANELIS PLUS project (43 articles, 5 proceedings papers, 1 working paper, 5 dissertations) and 4 publications from open access databases ( 3 article, 1 working paper). All publications have been generated by using the keyword vulnerability of nonprofit organizations. 


\section{RESULTS}

The total data-set, after removing duplicates, included 30 publications: 17 articles, 1 book chapter, 3 proceedings papers, 2 working papers, 6 dissertations and 1 wire feed. All the papers analyzed are published between 1991 - 2020 and focus on studying the vulnerability of the third sector organizations.

Table 3 The list of selected articles

\begin{tabular}{|c|c|c|c|c|c|c|c|c|c|c|c|c|c|}
\hline Articles & $\begin{array}{l}\text { Document } \\
\text { type }\end{array}$ & & $\begin{array}{l}\mathbf{C} \\
\mathbf{2}\end{array}$ & $\mathbf{D}$ & $\begin{array}{l}\mathbf{E} \\
\mathbf{1}\end{array}$ & $\begin{array}{l}\mathbf{E} \\
2\end{array}$ & $\mathbf{J}$ & $\mathbf{P}$ & $\mathbf{R}$ & $\begin{array}{l}\mathbf{S} \\
\mathbf{1}\end{array}$ & $\begin{array}{l}\mathbf{S} \\
\mathbf{2}\end{array}$ & $\begin{array}{l}\mathbf{S} \\
\mathbf{3}\end{array}$ & $\begin{array}{l}S \\
4\end{array}$ \\
\hline 1. Regulska J., 1999 & Article & & & & & & & & & & & & \\
\hline 2. Park S. Y., 2011 & Dissertation & & & & & & & & & & & & \\
\hline $\begin{array}{l}\text { 3. Silva B. \& Burger R., } \\
2015\end{array}$ & $\begin{array}{c}\text { Working } \\
\text { paper }\end{array}$ & & & & & & & & & & & & \\
\hline $\begin{array}{l}\text { 4. Andres-Alonso P., } \\
\text { Garcia-Rodriguez I., } \\
\text { Romero-Merino E., } 2015\end{array}$ & Article & & & & & & & & & & & & \\
\hline $\begin{array}{l}\text { 5. Despard, M. R., } \\
\text { Nafziger-Mayegun R.N., } \\
\text { Adjabeng B.K., Ansong } \\
\text { D., } 2017\end{array}$ & Article & & & & & & & & & & & & \\
\hline $\begin{array}{l}\text { 6. University of } \\
\text { Michigan, } 2017\end{array}$ & Wire feeds & & & & & & & & & & & & \\
\hline 7. Shupe E.T., 2020 & Dissertation & & & & & & & & & & & & \\
\hline $\begin{array}{l}\text { 8. Tuckman H. P. \& } \\
\text { Chang C. F., } 1991\end{array}$ & Article & & & & & & & & & & & & \\
\hline $\begin{array}{l}\text { 9. Chang C. F. \& } \\
\text { Tuckman H. P., } 1991\end{array}$ & Article & & & & & & & & & & & & \\
\hline $\begin{array}{l}\text { 10. Keating E., Fischer } \\
\text { M., Gordon T., Greenlee } \\
\text { J., } 2005\end{array}$ & $\begin{array}{l}\text { Working } \\
\text { paper }\end{array}$ & & & & & & & & & & & & \\
\hline $\begin{array}{l}\text { 11. Hodge M. M. \& } \\
\text { Piccolo R. F., } 2005\end{array}$ & Article & & & & & & & & & & & & \\
\hline 12. Lenaghan R. F., 2006 & Dissertation & & & & & & & & & & & & \\
\hline 13. Hodge M. M., 2006 & Dissertation & & & & & & & & & & & & \\
\hline $\begin{array}{l}\text { 14. Wang H-C. \& Liu Y. } \\
\text { A., } 2010\end{array}$ & $\begin{array}{c}\text { Proceedings } \\
\text { paper }\end{array}$ & & & & & & & & & & & & \\
\hline $\begin{array}{l}\text { 15. Hodge M. M. \& } \\
\text { Piccolo R. F., } 2011\end{array}$ & Article & & & & & & & & & & & & \\
\hline $\begin{array}{l}\text { 16. Surysekar K. \& } \\
\text { Turner E. H., } 2012\end{array}$ & Article & & & & & & & & & & & & \\
\hline 17. McNeal B. G., 2012 & Dissertation & & & & & & & & & & & & \\
\hline 18. Allen A. D., 2013 & Dissertation & & & & & & & & & & & & \\
\hline 19. Dayson C., 2013 & Article & & & & & & & & & & & & \\
\hline $\begin{array}{l}\text { 20. Arshad R., Deraman } \\
\text { N.A. C., Omar N., } 2013\end{array}$ & $\begin{array}{l}\text { Proceedings } \\
\text { paper }\end{array}$ & & & & & & & & & & & & \\
\hline $\begin{array}{l}\text { 21. MacIndoe H. \& } \\
\text { Sullivan F., } 2014\end{array}$ & Article & & & & & & & & & & & & \\
\hline $\begin{array}{l}\text { 22. Tevel E., Katz H., } \\
\text { Brock D. M., } 2015\end{array}$ & Article & & & & & & & & & & & & \\
\hline
\end{tabular}


An overview on the vulnerabilities of nongovernmental organizations

\begin{tabular}{|c|c|c|c|c|c|c|c|c|c|c|c|c|c|}
\hline Articles & $\begin{array}{l}\text { Document } \\
\text { type }\end{array}$ & $\begin{array}{l}\mathbf{C} \\
\mathbf{1}\end{array}$ & $\begin{array}{l}\mathbf{C} \\
\mathbf{2}\end{array}$ & $\mathbf{D}$ & $\begin{array}{l}\mathbf{E} \\
\mathbf{1}\end{array}$ & $\begin{array}{l}\mathbf{E} \\
\mathbf{2}\end{array}$ & $\mathbf{J}$ & $\mathbf{P}$ & $\mathbf{R}$ & 1 & $\begin{array}{l}\mathbf{S} \\
2\end{array}$ & & $\begin{array}{l}S \\
4\end{array}$ \\
\hline $\begin{array}{l}\text { 23. Andres-Alonso P., } \\
\text { Garcia-Rodriguez I., } \\
\text { Romero-Merino E., } 2016\end{array}$ & Article & & & & & & & & & & & & \\
\hline $\begin{array}{l}\text { 24. Woronkowicz J., } \\
2016\end{array}$ & Article & & & & & & & & & & & & \\
\hline $\begin{array}{l}\text { 25. Zhai R. L., Watson J., } \\
\text { Gilchrist D., Newby R., } \\
2017\end{array}$ & Article & & & & & & & & & & & & \\
\hline 26. Burde G., 2018 & Article & & & & & & & & & & & & \\
\hline $\begin{array}{l}\text { 27. Lu J., Lin W., Wang } \\
\text { Q., } 2019\end{array}$ & Article & & & & & & & & & & & & \\
\hline $\begin{array}{l}\text { 28. Mazanec J., } \\
\text { Bartosova J., } 2019\end{array}$ & $\begin{array}{l}\text { Proceedings } \\
\text { paper }\end{array}$ & & & & & & & & & & & & \\
\hline $\begin{array}{l}\text { 29. Tanner E.C., Su L., } \\
2019\end{array}$ & Article & & & & & & & & & & & & \\
\hline $\begin{array}{l}\text { 30. Önder M., Ayhan E., } \\
2020\end{array}$ & Book chapter & & & & & & & & & & & & \\
\hline
\end{tabular}

Legend: C1-CEEOL; C2-Clarivate Analytics (Web of science); D-DOAJ; E1-EBSCO; E2Emerald; J-JSTOR; P-ProQuest; R-RePEc; S-Sage; S2-ScienceDirect; S3-Scopus; S4Springer.

Source: Author, 2019

Most papers (23 publications) have been published over the past 10 years. This means that the researchers have begun to attach increasing importance to this area of research. All the 30 publications are written in English.

Considering the limited number of publications identified, it is obvious that, to this point, little evidence of nongovernmental organizations' vulnerabilities has been available. The analysis of the articles selected for this review shows that most of the literature on nongovernmental organizations' vulnerability tends to focus on their financial vulnerability (25 publications). Moreover, the researchers focused on a variety of approaches to defining, operationalizing and understanding the concept of vulnerability of nongovernmental and nonprofit entities.

The main aspects regarding the nongovernmental organizations' financial vulnerability arising from the articles analyzed are the following:

\section{- It represents one of the biggest challenges of the third sector;}

Keating, Fischer, Gordon and Greenlee (2005) consider the financial vulnerability of NGOs a new field of study because the papers analyzing it are relatively recent. As stated in Chang and Tuckman (1991), a financially vulnerable organization fails to avoid cutbacks or reduction of services provided to beneficiaries in times of financial crisis. Furthermore, the two authors highlight the link between the financial vulnerability of NGOs and attrition. Thus, when the deficits of these entities become very large and/or when they can no longer justify their functioning, they cease their activity. 
However, Keating, Fischer, Gordon and Greenlee (2005) argue that predicting the time when the NGO has to reduce expenses and, implicitly the services provided to the beneficiaries is quite difficult. The models used fail to be comprehensive enough because managers want to fulfil the organization's mission at all costs even in case of decreasing the net income or net assets.

More specifically, according to Dayson (2013), the financial sustainability of the nongovernmental sector has not received significant attention from the researchers, although it has often been mentioned by politicians and decision-makers. Moreover, the author points out that there are many obstacles to ensuring the financial stability of nonprofit entities and their study could provide answers to organizations in crisis or failure situations. In addition, in the opinion of Önder \& Ayhan (2020), the level of financial resources, the method of operation, the size of the organization and the managerial competence of the leadership team have a beneficial effect on diminishing the financial vulnerability of NGOs.

As regards to MacIndoe \& Sullivan's article (2014), it can be observed that collaborations are considered a strength of third sector organizations, turning them into effective and efficient actors in the market. Financially vulnerable entities are less involved in collaboration with others. This weakness should come to the attention of public and private funders who place great emphasis on NGO cooperation in order to increase their financial sustainability.

According to Silva \& Burger (2015), the inability of NGOs to adapt to financial difficulties threatens the fulfilment of their mission and implicitly the provision of services to the beneficiaries. This situation could be amplified if cooperation with donors, government as well as individuals is difficult. In the opinion of other authors (Despard, Nafziger-Mayegun, Adjabeng and Ansong, 2017) financial vulnerability is a common feature of NGOs, and the difficult conditions imposed by international donors and some options such as shorter duration of funding and lack of general funding might not reduce it, but on the contrary it may actually contribute to this vulnerability. This situation has a negative effect on the services provided to the community as well as on keeping the best employees in the organizations. Moreover, Andres-Alonso, GarciaRodriguez and Romero-Merino (2015) consider that nongovernmental organizations are subject to financial shocks in times of crisis. In this situation, large organizations have a higher chance of survival compared to small ones because they are more visible on the market and their volume of income is higher. Furthermore, McNeal (2012) points out that the main nonprofit entities' funding sources significantly affect their behavior in the event of a financial shock.

\section{- There are several factors underlying the financial vulnerability of NGOs;}

Tuckman and Chang (1991) identify several factors influencing the financial situation of NGOs: the generosity of those who support the organization, its financial stability, the diversity of sources of income, the survival to income fluctuation, the size of the capital.

Silva \& Burger (2015) propose dividing the factors influencing the 
financial vulnerability of NGOs into two categories: internal factors, alternative ways of getting funds, experience and the characteristics of the organization and external factors, economic shocks, donors' decision to cut the funds provided to these organizations, failure to receive funds on time. Moreover, these authors consider that diversified sources of income and flexibility in allocating funds could have a positive impact on reducing financial vulnerability compared with funds obtained from donors having rigid budgets and imposing rigid reporting standards. On the other hand, Despard, NafzigerMayegun, Adjabeng and Ansong (2017) highlights several factors such as status, size, community, access to the internet and type of mission do not affect financial vulnerability, while the country in which the NGO operates significantly influences it.

- There are several criteria/indicators in literature for determining the financial vulnerability of NGOs;

The first authors that classified nongovernmental organizations depending on their financial vulnerability were Tuckman and Chang (1991). They used four criteria: equity balances, revenue concentration, administrative costs and operating margins. Using the same criteria, other authors (Silva \& Burger, 2015) have concluded that revenue concentration and surplus margin are key elements in determining the financial vulnerability of nonprofit organizations. More recently, Tevel, Katz and Brock (2015) have tested Tuckman and Chang's model and concluded that this is the most effective model for assessing the financial vulnerability of an NGO in literature. Their analysis has highlighted the usefulness of two of the four variables proposed by Tuckman \& Chang in 1991, revenue diversification and management costs, to which they added a third variable, organizations' net assets.

The likelihood of financial vulnerability was also investigated by Keating, Fischer, Gordon and Greenlee (2005). Their analysis is based on four dichotomous measures related to the ability of an NGO to fulfil its mission: insolvency risk, financial disruption, funding disruption and program disruption. The model proposed by these authors provides sufficient explanations to understand the conditions generating the financial vulnerability of an organization.

A more recent approach (Andres-Alonso, Garcia-Rodriguez and Romero-Merino, 2016) propose three criteria that an NGO should met simultaneously to be considered highly financially vulnerable: a significant decline in net assets over the last three years; a small percentage of all assets to debt; a reduced ratio of the existing assets with reference to short-term debt. On the other hand, Burda (2018) put forward an improved methodology that uses the hazard analysis method in order to investigate the financial vulnerability of nonprofit entities.

An interesting analysis belongs to Wand \& Liu (2010) who have examined the financial vulnerability of nonprofit entities of private universities in Taiwan. Starting from the model of Trussel (2002), the above-mentioned authors have proposed a model based on four financial indicators measuring the financial vulnerability of the organizations operating in the field of 
education: financial vulnerability as a dependent variable, as well as independent variables, debt ratio, revenue concentration, surplus margin (replaced by savings) and size of the organization.

The most recent paper in the field (Mazanec \& Bartosova, 2019) analyzes the financial stability of non-profit organizations in the Slovak Republic and proposes a model based on several variables: seniority, legal form, type of organization (commercial or non-commercial), share of sales revenue in total revenue, share of fixed assets in total assets, etc. According to its authors, such a model could be very useful for Slovak practitioners, especially since most articles and models in the literature focus on the financial vulnerability of American NGOs that have a different financial situation than Slovak organizations.

- It arises from the need for resources and dependence on external organizations;

Aliquippa's (2013) findings suggest that nongovernmental entities depend to a large extent on outside organizations in obtaining the resources needed in order to carry out their activities. However, the higher their dependence on the external environment is, the more their financial vulnerability increases.

- It is one of the factors that cause third sector organizations to diversify their revenue;

According to Despard, Nafziger-Mayegun, Adjabeng and Ansong (2017), revenue diversification is an essential element in reducing financial vulnerability. Moreover, examining each type of income and the amount of funding offered could provide useful explanations for determining this vulnerability. On the opposite pole, by synthetizing and assessing all existing studies in the field, Lu, Lin and Wang (2019) have found that revenue diversification had almost no effect on the financial vulnerability of organizations.

Revenue diversification is also supported by Hodge \& Piccolo (2015) as well as Surysekar \& Turner (2012). Their studies reveal that the diversity of resources has a positive impact on the financial stability of an NGO, which becomes less financially vulnerable. Moreover, Lenaghan (2006) mentions that NGOs' survival and development requires internal (service fees, fundraising events etc.) and external (grants, subsidies etc.) resources which should be adequate, diversified and well-managed. Furthermore, Woronkowicz (2016) supports the investment in various facilities as a means of reducing the financial vulnerability of NGOs and of positively influencing the net assets at least four years after the investment intervention.

On the other hand, Andres-Alonso, Garcia-Rodriguez and RomeroMerino (2015) highlights the need to distinguish between public and private income provided to NGOs, especially as they depend to a large extent on public funds, but also because these sources of income are subject to restrictions and controls by the authorities.

- There is a strong connection between the effectiveness of the board and the diminishing of the nongovernmental organizations' 


\section{financial vulnerability.}

The link between the board of directors and the financial vulnerability of the nonprofit organization is investigated by Hodge (2006). According to this author, the role of the board of directors in the success of an entity is significant, especially as this decision-maker represents the key element in ensuring the stability of the organization. This idea is also supported by Hodge \& Piccolo (2011) as well as Önder \& Ayhan (2020) who asserted that the board of directors had a fundamental role in developing the financial and other resources of the organization. Moreover, there is a close connection between the activity of the board of directors and the financial health of a nonprofit entity. Furthermore, the above-mentioned authors pointed out that privately funded NGOs are characterized by a greater dependence on the effectiveness of the board of directors than those funded mainly by government or commercial sources.

In analyzing the relationships between the board of directors' configuration and the financial vulnerability of NGOs, Arshad, Deraman and Omar (2013) emphasized that the professional affiliation of board members has a positive influence on the financial stability of nonprofits because these decision-makers seek to provide resources in line with the organizations' needs.

There are few publications (three articles and two dissertations) out of the 30 identified for this review which are not limited to the financial vulnerability of nongovernmental organizations. One of the authors (Park, 2011) mentions that the vulnerability of nongovernmental entities might arise not only because of their financial instability but also because of other issues such as political interests or staff fluctuations that could lead to their change or disappearance. Moreover, according to Regulska (1999), nongovernmental organizations are struggling with their internal deficiencies, while citizens are not too eager to support them through volunteer work. Furthermore, the historical heritage of each nation continues to influence the evolution of the sector.

Other author (Zhai, Watson, Gilchrist and Newby, 2017) identifies several key elements such as related to costs, program spending, reduced capacity to meet the objectives for assessing the vulnerability of Australian NGOs as well as the underlying causes of this situation: lack of experience of the board chairman, lack of strategic planning, lack of a methodology for reviewing the performance of staff and the board of directors' members.

Tanner \& Su (2019) is an interesting study. Starting from vulnerable people's resistance to the services provided by NGOs aiming to improve their situation, the authors analyze the influence of perceived vulnerability on the NGO services' benefits which affect the consumers' desire to use them. As regards the most recent publication in the field of NGO vulnerability (Shupe, 2020), it analyzes the phenomenon of vulnerability experienced by the new board of directors' members of local nonprofits as gaining knowledge in the workplace and developing the relations with others: members, stakeholders, beneficiaries etc. 


\section{CONCLUSIONS}

The aim of this article is to gain insight into the vulnerabilities of nongovernmental organizations. A total of 30 publications on nongovernmental sector's vulnerability provided by 12 international databases were examined. Although they are of great importance because they could impede or postpone the achievement of the organization's objectives, relatively little attention has been paid by researchers to the nongovernmental sector's vulnerabilities. That is why future research should be continued in this area in order to point out the effects of this issue on the nongovernmental sector.

Despite significant achievements, mainly in satisfying the citizens' needs, the nongovernmental sector has several vulnerabilities, the authors of the identified publications focusing especially on the financial issues.

The present paper aims to contribute to a relatively under-researched area summarizing results which could guide the decision makers in the field. Moreover, this article could represent a source of information for human resources of the third sector (members, employees, volunteers) in order to increase their chances of success.

As regards limitations, this study does not have a systematic view of this field of research because publications are spread across many databases and the present paper only analyzed the articles included in 12 international databases. Moreover, due to the selection of keywords used for identifying the publications, some papers matching the research might have not been included in the analysis because they did not contain appropriated keywords in title.

Taking into account the limited number of papers analyzed, these results should be considered suggestive than conclusive. Therefore, further research is necessary in this field and future studies might attempt to identify and describe more thoroughly all the nongovernmental sector's vulnerabilities as well as the solutions to reduce or eliminate them. 


\section{REFERENCES}

Adirondack, S.M. (1999). Managementul pur şi simplu? Management eficient pentru organizaţiile neguvernamentale. Bucureşti: Editura Fundaţiei pentru Dezvoltarea Societăţii Civile.

Ahmed, S., Potter, D.M. (2006). NGO in International Politics. Boulder \& London: Kumarian Press.

Allen A. D. (2013). Vulnerability and resource dependency: A quantitative study of nonprofit organizations in Alabama's Black Belt. Minneapolis: Capella University.

Andres-Alonso, P., Garcia-Rodriguez, I., Romero-Merino, E. (2015). The Dangers of Assessing the Financial Vulnerability of Nonprofits Using Traditional Measures: The Case of the Nongovernmental Development Organizations in the United Kingdom. Nonprofit Management \& Leadership, 25(4), 371-382. https://doi.org/10.1002/nml.21134

Andres-Alonso, P., Garcia-Rodriguez, I., Romero-Merino, E. (2016). Disentangling the Financial Vulnerability of Nonprofits. VOLUNTAS: International Journal of Voluntary and Nonprofit Organizations, 27(6), 2539-2560. https://doi.org/10.1007/s11266-016-9764-6

ANELIS (n.d.). Retrieved from http://www.anelisplus.ro/.

Aromataris, E. \& Pearson, A. (2014). The Systematic Review: An Overview. Synthesizing research evidence to inform nursing practice. The American Journal of Nursing, 114(3), 53-58. doi: 10.1097/01.NAJ.0000444496.24228.2c

Arshad, R., Deraman, N.A. C., Omar, N. (2013). Exploring board composition and financial vulnerability in non-profit organizations. Rome, Italy: The 22nd International Business Information Management Association Conference, IBIMA.

Burde, G. (2018). Improved Methods for Predicting the Financial Vulnerability of Nonprofit Organizations. Administrative Sciences, 8(3), 1-8. doi:10.3390/admsci8010003

Chang, C. F. \& Tuckman, H. P. (1991). Financial vulnerability and attrition as measures of nonprofit performance. Annals of Public and Cooperative Economics, 62(4), 655-672. https://doi.org/10.1111/j.14678292.1991.tb01372.x

Cihodariu, M. (2013). Impactul organizaţiilor neguvernamentale asupra relaţiilor internaţionale. Retrieved from https://www.youtube.com/watch?v=7hg1 cXJWzqA

Dang, L. (2009). Non-Governmental Organizations (NGOs) and Development: An Illustration of Foreign NGOs in Vietnam. Retrieved from https://etd.ohiolink.edu/!etd.send_file?accession=ohiou1243905289\& disposition=inline

Dayson, C. (2013). Understanding financial vulnerability in UK third sector organisations: methodological considerations and applications for policy, practice and research. Voluntary Sector Review, 4(1), 19-38. https://doi.org/10.1332/204080513X663796

Despard, M. R., Nafziger-Mayegun, R.N., Adjabeng, B.K., Ansong, D. (2017). 
Does Revenue Diversification Predict Financial Vulnerability Among Non-governmental Organizations in sub-Saharan Africa? Voluntas, 28(5), 2124-2144. https://doi.org/10.1007/s11266-017-9835-3

Esayas, E. \& Mulugeta, S. (2020). Analysis of socioeconomic vulnerability of street vendors: case study for Dire Dawa city, Eastern Ethiopia. Theoretical and Empirical Researches in Urban Management. 15(2), 49-65. Retrieved from http://www.um.ase.ro/no152/4.pdf

Harvey, D. (2005). A Brief History of Neoliberalism. Oxford: Oxford University Press.

Hodge, M. M. (2006). Nonprofit board effectiveness, funding source, and financial vulnerability. Retrieved from http://etd.fcla.edu/CF/CFE0000974/Hodge_Matthew_ _ M_200605 _PhD.pdf

Hodge, M. M. \& Piccolo, R. F. (2011). Nonprofit board effectiveness, private philanthropy, and financial vulnerability. Public Administration Quarterly, 35(4), 520-550. Retrieved from https://www.jstor.org/stable/23209327.

Hodge, M. M. \& Piccolo, R. F. (2005). Funding Source, Board Involvement Techniques, and Financial Vulnerability in Nonprofit Organizations A Test of Resource Dependence. Nonprofit Management \& Leadership, 16(2), 171-190. https://doi.org/10.1002/nml.99

Hudson, M. (1995). Managing Without Profit. Londra: Penguin Books.

Jura, C. (2003). Rolul organizaţiilor neguvernamentale pe plan internaţional. Bucureşti: Editura All Beck.

Kacarski, A. \& Kovachevski, D. (2019). Internal marketing influence on organizational culture and service quality in Macedonian companies. Management Research and Practice, 11(4), 11-22. Retrieved from http://www.mrp.ase.ro/no114/f2.pdf

Keating, E., Fischer, M., Gordon, T., Greenlee, J. (2005). Assessing Financial Vulnerability in the Nonprofit Sector. Retrieved from http://seachangecap.org/wp-content/uploads/2016/02/AssessingFinancial-Vulnerability-in-the-Nonprofit-Sector. pdf

Lenaghan, R. F. (2006). A model of cash flow components and resource dependency as determinants of short-run financial vulnerability in nonprofit organizations. Retrieved from https://search.proquest.com/openview/fd794ccd16f2c4727087e0679e $73 \mathrm{ec} 36 / 1$ ? pq-origsite $=$ gscholar\&cbl $=18750 \&$ diss $=\mathrm{y}$.

Lu, J., Lin, W., Wang, Q. (2019). Does a More Diversified Revenue Structure Lead to Greater Financial Capacity and Less Vulnerability in Nonprofit Organizations? A Bibliometric and Meta-Analysis. Voluntas, 30(3), 593-609. https://doi.org/10.1007/s11266-019-00093-9

MacIndoe, H. \& Sullivan, F. (2014). Nonprofit Responses to Financial Uncertainty: How Does Financial Vulnerability Shape Nonprofit Collaboration? Journal of Management and Sustainability, 4(3), 1-15. DOI: $10.5539 / j m s . v 4 n 3 p 1$

Mazanec, J. \& Bartosova, J. (2019). Financial vulnerability of non-profit 
organizations in the Slovak Republic. Granada, Spain: International Business Information Management Association Conference Education Excellence and Innovation Management through Vision 2020, IBIMA.

McNeal, B. G. (2012). Measuring the Financial Vulnerability of MembershipBased Nonprofit Business Leagues Using Accounting Ratios. Scottsdale: Northcentral University.

Naros, M.S. \& Simionescu, M. (2019). The role of education in ensuring skilled human capital for companies. Theoretical and Empirical Researches in Urban Management. 14(1), 75-84. Retrieved from http://www.um.ase.ro/no141/4.pdf

Nicolae, I. (2010). Managementul şi cultura organizaţiilor nonguvernamentale din România. Retrieved from https://cis01.central.ucv.ro/upload/lucrari_dr/199_rez-ro.pdf.

Önder, M. \& Ayhan, E. (2020). Financial Vulnerability of NGOs in Southeast Anatolia and Mediterranean Regions. In: Bilgin M., Danis H., Karabulut G., Gözgor G. (eds) Eurasian Economic Perspectives. Eurasian Studies in Business and Economics, vol 12/1. Springer, Cham.

Park, S.Y. (2011). Cultural politics of NGOs in neoliberal era: The flexibility and vulnerability of non-governmental organizations (NGOs) supporting North Koreans in South Korea. Retrieved from https://pqdtopen.proquest.com/doc/ 892070776.html?FMT=AI

Păceşilă, M. (2016). Organizații neguvernamentale-nonprofit. De la teorie la practică. Bucureşti: Editura ASE.

Păceșilă, M. \& Colesca, S.E. (2019). Professional training of Romanian civil servants in territorial administrative units. Administratie si Management Public, (33), 133-146, DOI: 10.24818/amp/2019.33-08

Pinfari, M. (2016). Regional Organizations in the Middle East. Retrieved from https://www.oxfordhandbooks.com/view/10.1093/oxfordhb/978019 9935307.001.0001/oxfordhb-978019 9935307-e-86

Regulska, J. (1999). NGOs and Their Vulnerabilities during the Time of Transition: The Case of Poland. Voluntas: International Journal of Voluntary and Nonprofit Organizations, 10(1), 61-71. https://doi.org/10.1023/A:1021443804559

Roshayani, A., Mohd Nisham, M., Nur Erzan, R., Ruhaini, M., Ramesh, N. (2018). Desired board capabilities for good governance in non-profit organizations. Administratie si Management Public, 30, pp. 127-140. DOI:10.24818/amp/2018.30-09

Salamon, L.M. \& Sokolowski, S.W. (2014). The third sector in Europe: towards a consensus conceptualization. Retrieved from https://thirdsectorimpact.eu/site/assets/ uploads/documentations/tsiworking-paper-no-2-third-sector-europe-towards-consensusconceptualizati on/TSI-Wrkg-Ppr-2-Conceptualiza-fnl-2-17-15-.pdf

Shupe, E.T. (2020). Risk, Uncertainty and Emotional Exposure: How New CEO's of Local Non-profits Experience Vulnerability as They Learn 
in the Workplace, Retrieved from https://search.proquest.com/openview/48356e63cc0d5031cb84405cd $2269 \mathrm{c} 14 / 1$ ?pq-origsite $=$ gscholar \&cbl $=18750 \&$ diss $=\mathrm{y}$

Silva, B. \& Burger, R. (2015). Financial vulnerability: an empirical study of Ugandan NGOs. CIRIEC (España revista de economía pública, social y cooperativa), 15, 1-25.

Surysekar, K. \& Turner, E. H. (2012). The Association Between Fundraising Efficiency, Financial Vulnerability, And Subsequent Donations To Not-For-Profits. The Review of Business Information Systems, 16(3), 157-164. https://doi.org/10.19030/rbis.v16i3.7133

Tanner, E.C. \& Su, L. (2019). Reducing perceived vulnerability to increase utilization of nonprofit services. Journal of Services Marketing, 33(3), 344-355. https://doi.org/10.1108/JSM-12-2017-0434

Tevel, E., Katz, H., Brock, D. M. (2015). Nonprofit Financial Vulnerability: Testing Competing Models, Recommended Improvements, and Implications. VOLUNTAS: International Journal of Voluntary and Nonprofit Organizations. 266(6), 2500-2516. https://doi.org/10.1007/s11266-014-9523-5

Trussel, J. M. (2002), Revisiting the Prediction of Financial Vulnerability. Nonprofit Management \& Leadership, 13(1), 17-31. https://doi.org/10.1002/nml.13103

Tuckman, H. P. \& Chang, C. F. (1991). A Methodology for Measuring the Financial Vulnerability of Charitable Nonprofit Organizations. Nonprofit and Voluntary Sector Quarterly, 20(4), 445-460. https://doi.org/10.1177/089976409102000407

Uman, L.S. (2011). Systematic Reviews and Meta-Analyses. Journal of the Canadian Academy of Child and Adolescent Psychiatry, 20(1), 57-59. Retrieved from https://www.ncbi.nlm.nih.gov/pmc/articles/PMC3024725/

University of Michigan. (2017). Third-Sector Research; Study Results from University of Michigan Provide New Insights into Third-Sector Research (Does Revenue Diversification Predict Financial Vulnerability Among Non-governmental Organizations in sub-Saharan Africa?), Politics \& Government Week, 483.

Wang, H-C. \& Liu, Y. A. (2010). Performance and vulnerability of non-profit organization in Taiwan - Sampling in private universities, Tainan, Taiwan: International Symposium on Computer, Communication, Control and Automation.

Woronkowicz, J. (2016). Is Bigger Really Better? The Effect of Nonprofit Facilities Projects on Financial Vulnerability. Nonprofit Management \& Leadership, 27(1), 79-94. https://doi.org/10.1002/nml.21209

Zhai, R. L., Watson, J., Gilchrist, D., Newby, R. (2017). Non-profit vulnerability: An exploratory study. Financial Accountability \& Management, 33(4), 373-390. https://doi.org/10.1111/faam.12129 